\title{
Evaluation of Primary Health Care Services Which is Provided to Refugees within a Public Health Center
}

\section{Bir Toplum Sağlığı Merkezi Örneğinde Sı̆̆ınmacı ve Mültecilere Verilen Birinci Basamak Sağlık Hizmetlerinin Değerlendirilmesi}

\author{
Olgu Aygün ${ }^{1 *}$, Özden Gökdemir², Ülkü Bulut ${ }^{2}$, Seval Yaprak ${ }^{3}$, Dilek Güldal ${ }^{3}$
}

\begin{abstract}
Background: In recent years, so many people have left their counties because of the war or social, political and economic reasons. This study aims to evaluate the applications of Syrian refugees to a public health center to describe the health care provided to them. Method: The study is intended as a two-part in regard with the mixed design of the study. The first part planned as single-center, descriptive study to be performed with health records of the Syrian asylum seekers and refugees admitted İzmir- Karabaglar community health center within one year. In the second part semi-structured interviews with three doctors who were working in the same center, taking care of Syrian patients, was planned to understand their experiences and views on this service. For quantitative data SPSS for windows 20 program is used and descriptive analysis are performed. Thematic analysis was used for evaluating interviews. Results: 891 applications were made to Karabaglar community health center within one year and the median of the applicants was 4 . The most prevalent reason for application was enfections $(519 ; 58.2 \%)$ and the number of refugees who applied for preventive care was very low ( $(90 ; 10.1 \%)$. The number of laboratory tests was $41(4.6 \%)$ patients and the most requested test was urinary analysis. $502(56.3 \%)$ application resulted with a prescription, the number of antibiotics and analgesics were the highest. Doctors who provide service were not satisfied with the care they give. They were having very deep communication problems related with both different cultur and language, hard time to understand patient and the disease. They stated that there is a need of different regulations. Conclusions: Refugees and asylum seekers do not receive the necessary health care they need. Physicians in primary care who take care of these people are thinking that they are not competent and not helpful for these patients.
\end{abstract}

Key words: Refugees, asylum seekers, primary health care, health needs

\section{ÖZET}

Giriş: Son yıllarda milyonlarca insan, savaşlar başta olmak üzere siyasi, ekonomik ve sosyal sebeplerle öz vatanlarından ayrılarak yabancı ülkelere sığınmak zorunda kalmıştır. Çalışmamızda, sayıları gittikçe artan Suriyeli sığınmacıların, aldıkları birinci basamak sağlık hizmetlerini tanımlayabilmek amacı ile bir toplum sağlığı merkezine yapılan bir yıllık başvurular değerlendirilmiştir. Yöntem: Çalışma karma desende olup, iki aşamalı olarak tasarlanmıştır. İlk aşamada, İzmir-Karabağlar toplum sağlığı merkezine bir yıl içerisinde başvuran Suriyeli sığınmacı hastalara ait kayıtlardan elde edilen verilerle, tek merkezli, tanımlayıcı bir araştırma olarak planlanmıştır. İkinci bölümde ise, aynı birimde Suriyeli sı̆̆ınmacılara, poliklinikte hizmet veren üç doktorla yarı yapılandırılmış görüşme yapılarak deneyimlerini ve görüşlerini aktarmaları istenmiştir. Kantitatif veriler, SPSS 20 programında değerlendirilerek tanımlayıcı analizler yapılmış, görüşmeler ise tematik analiz yöntemi ile değerlendirilmiştir. Bulgular: Karabağlar Toplum Sağlığı Merkezi'ne, bir yıl içerisinde yapılan başvuru sayısı 891 olup, ortanca yaş 4 olarak bulunmuştur. En sık başvurma nedeni enfeksiyon $(519 ; \% 58,2)$ olup, önleyici bakım için başvuranların oranı oldukça düşüktür $(90 ; \% 10,1) .41(\% 4,6)$ hastaya tetkik istenmiş, en sık istenen tetkik ise tam idrar analizi olmuştur. Öte yandan reçete verilen hasta sayısı 502 (\%56,3) olup, en çok antibiyotik ve analjezik ilaçlar reçete edilmiştir. Bakım veren hekimler, verdikleri hizmeti yeterli bulmadıklarını, hem kültürel hem de dil olarak önemli bir iletişim sorunu yaşadıklarını, hasta ve hastalıkları anlamakta zorluk yaşadıklarını, farklı çözümler üretilmesi gerektiğini belirtmişlerdir. Sonuç: Toplum sağlı̆̆ı merkezinde, sığınmacılara verilen sağlık hizmetleri ile ilgili; ilk ve öncelikli olarak dil farklılığından kaynaklanan sorunlar olduğu gözlemlenmiştir. Başvuruda bulunan kişilerin, daha önceki sağlı verilerine ulaşılamaması, bebek, kadın ve çocuk izlem yapılması konusunda zorlaştırıcı bir faktör olarak bulgulanmıştır.

Anahtar kelimeler: Mülteci, sığınmacı, birinci basamak sağlık hizmeti, sağlık gereksinimleri

Received / Geliş tarihi: 17.08.2015, Accepted / Kabul tarihi: 18.09. 2015

${ }^{1}$ Karabağlar 2 Nolu Asm, İzmir, ${ }^{2}$ Balçova Tsm, İzmir ${ }^{3}$ Dokuz Eylül Üniversitesi Tıp Fakültesi Aile Hekimliği Anabilim Dalı, İzmir, *Address for Correspondence / Yazışma Adresi: Olgu Aygün, Karabağlar 2 Nolu Asm, İzmir- TÜRKIYYE, E-mail: olgu4780@gmail.com

Aygün O, Gökdemir Ö, Bulut Ü, Yaprak S, Güldal D. Bir Toplum Sağlığı Merkezi Örneğinde Sığınmacı ve Mültecilere Verilen Birinci Basamak Sağlık Hizmetlerinin Değerlendirilmesi. TJFM\&PC, 2016;10(1):6-12. DOI: 10.5455/tjfmpc.199143 


\section{GíRiş}

Savaş, küresel bir sağlık sorunudur. ${ }^{1}$ Savaşlar ölüm, yaralanma, hastalıklar ve bunlardan kurtulanların tüm yaşamını etkileyen uzun dönem etkilere neden olur. Savaş sırasında, bir savaşana karşılık bir sivil doğrudan yaşamını kaybederken, yiyecek, su gibi yaşamsal gereksinimlerini karşılayamadıkları için 14-15 kişi ölmekte, daha fazlası ise fiziksel ve psikolojik olarak yaralanmaktadır. ${ }^{2}$ Öte yandan savaş, insanların kitleler halinde kendi ülkelerini terk ederek başka ülkelere iltica etmelerine yol açmaktadır. Dünyada, savaş nedenli yerinden olmuş kişi sayısı yaklaşık 13,5 milyondur. Afganistan'da yaklaşı bir milyon, Angola'da 3,8 milyon, Sudan'da ise yaklaşık 4 milyon kişi yaşadıkları yerden ayrılmak zorunda kalmışlardır. ${ }^{3}$ Benzer şekilde mülteci ya da sığınmacıların yoğun olarak bulunduğu bölgelerde sağlık kurumlarına ulaşım sıkıntısı, kötü beslenme, kötü yaşam koşulları, dil sorunu, eğitim düzeyinin düşmesi, yetersiz temizlik koşulları, ekonomik yetersizlik, sosyal güvence olmaması gibi nedenler sağlık üzerine olumsuz etki etmektedir. ${ }^{4}$ Göç fikrinin ortaya çıkmasının bile travmayı başlattığı bildirilmektedir. ${ }^{5}$

2003 y1lından beri Orta Doğu bölgesinde süren savaş ve şiddet olayları komşu ülkeleri de etkilemektedir. Bu durum, büyük toplumsal yer değiştirmelere sebebiyet vermektedir.

2011 yılı bahar aylarından bu yana, yaşanan iç savaş nedeni ile yaklaşı 2,5 milyon Suriyeli ülkesini terk edip komşu ülkelere (Türkiye, Irak, Ürdün, Lübnan ve Misır) sığınarak buralardaki mülteci kamplarında yaşamak zorunda bırakılmıştır. Yaklaşık 5 milyon Suriyeli ise ülke içinde göç etmek zorunda kalmıştır. ${ }^{8}$ Birleşmiş Milletler (BM) verilerine göre 4-6 milyon, Suriyeli kaynaklara göre ise 7 milyon Suriyeli 2011'den bugüne kadar ülkesini terk etmiştir. ${ }^{9}$

Türkiye tarafından geçici koruma sağlanan Suriyeliler, ülkemizdeki sığınmacı varlığı içinde en yoğun grubu oluşturmaktadır. Sadece 2012 Nisan ayında ülkeye 300-400 bin civarında Suriyeli sığınmış, 2013'te bu sayı 500,000'i aşmıştır. ${ }^{10}$ Türkiye'de ilk olarak Hatay Reyhanlı, Yayladağı ve Altınözü ilçelerinde olmak üzere Suriye ile sınır kapılarına yakın bölgelere 17 kamp kurulmuştur (Şanlıurfa, Kahramanmaraş, Osmaniye, Adıyaman, Adana, Kilis, Malatya, Gaziantep, Hatay). Ancak birçok merkezde, kayıtlı olmayan sığınmacıların da bulunduğu bilinmektedir. 1994 yılında düzenlenen yönetmelikteki "açık kap1 politikası" nedeniyle mülteci ya da sı̆̆ınmacı konumunun yerini "misafir" konumu almıştır. ${ }^{11}$ Temmuz 2001 tarihli Birleşmiş Milletler Mülteciler Yüksek KomisyonuUNHCR tarafından alınan bir karar ile ise mültecilere "uluslararası koruma statüsü" getirilmiştir. ${ }^{12} \mathrm{Bu}$ yönetmelik sığınmacı kabul eden ülkelere bazı yükümlülükler getirmiştir. Bunlar arasında mültecilere barınma olanağı sağlanması, yiyecek, giyecek, sağlık gibi temel gereksinimlerinin karşılanması; çocuk, sakat, işkence görmüş, tecavüze uğramış kişiler gibi özel gereksinimleri olanların gereksinimlerinin karşılanması ve 18 yaş altındakilere eğitim olanağı verilmesi en önemlileridir. ${ }^{13} \mathrm{Bu}$ kapsamda, sığınmacıların birinci basamak sağlık hizmetleri de dahil olmak üzere, her çeşit sağlık harcaması Türkiye Cumhuriyeti devletince karşılanmaktadır.

Sığınmacıların ihtiyaçlarına ve onlara sağlanan hizmetlere ilişkin literatürde sınırlı sayıda bilgi mevcuttur. Kamplarda ya da geçici yerleşim yerlerinde bulunan göçmenlerin sağlık sorunları öngörülebilir, kontrol edilebilir ve tedavi edilebilir nitelikte olup değerlendirilmesi daha kolaydır. ${ }^{14}$ Türkiye'nin her yerine dağılmış ve kayıt altında olmayan nüfus için aynı şeyleri söylemek olası değildir. Serbest dolaşan ve kayıt altında olmayan Suriyeli göçmenlerin hangi sağlık sorunları ile sıklıkla karşılaştıkları, bunların oluşturduğu iş yükü ve ekonomik yük hakkında bilgi bulunmamaktadır. Çalışmamızın amacı, birinci basamak sağlık hizmetlerine başvuran Suriyeli göçmenlere verilen hizmetlerin bir Toplum Sağlığı Merkezi (TSM) örneğinde incelenmesidir.

\section{YÖNTEM}

Araştırma karma desende tasarlanmıştır. Bilindiği gibi, karma desen birden fazla araştırma yönteminin bir arada kullanılması demek olup, bizim çalışmamızda da niceliksel ve niteliksel araştırmalar aynı araştırma sorusunu yanıtlamak için kullanılmıştır. ${ }^{15}$ Çalışmanın birinci bölümü, İzmir-Karabağlar Toplum Sağlığı Merkezine 10.10.2013 - 10.10.2014 tarihleri arasında başvuran Suriyeli sığınmacı ve mülteci hastalara ait kayıtlardan elde edilen verilerle tek merkezli, tanımlayıcı bir araştırma olarak planlanmıştır. Kayıtlarda cinsiyet, yakınma, istenen tanı testi, reçete verilip verilmediği, reçete edilen ilaçlar bulunmaktadır.

Başvuru nedenleri ilgili oldukları sistemler çerçevesinde altı grupta toplanmış olup aşı, gebe izlemi nedenli başvurular koruyucu hekimlik başlığı altında birleştirilmiştir.

Toplanan veriler SPSS 20.00 programinda değerlendirilmiş, tanımlayıcı analizler arasından ortalama, ortanca ve frekanslar elde edilmiştir.

İkinci bölümde ise Karabağlar TSM bünyesinde sadece Suriyeli hastalara hizmet veren Suriyeli Hasta Polikliniği'nde hizmet veren üç doktora; çalışma ortamında yaşadıkları sıkıntılar, mesleki olarak sığınmacılara hizmet veriyor olmayı nasıl değerlendirdikleri ve hizmetin daha etkili ve yararlı olabilmesi için düzeltilmesi gereken şeylerin neler olduğu sorulmuştur. Yanıtlar işitsel olarak kayıt edilmiş, kayıt sonrası yazılı hale getirilmiş, araştırmacılar OA ve DG tarafından tematik analiz yöntemi ile değerlendirilmiştir. 
Çalışma için 09.07.2015 tarihinde 2146-GAO protokol ve 2015/17-30 karar no'lu etik kurul izni Dokuz Eylül Üniversitesi Girişimsel Olmayan Araştırmalar Etik Kurulundan alınmıştır.

\section{BULGULAR}

\section{Başvuruların Değerlendirilmesi}

10.10.2013 - 10.10.2014 tarihleri arasında Karabağlar TSM mülteci ve sığınmacı polikliniğine 891 başvuru yapılmıştır. Bu rakam, 260 iş gününe bölündüğünde günde ortalama 3,4 başvuru olduğu anlaşılmaktadır. Başvuruların hepsi farklı kişilere aittir. TSM'e başvuranların ortalama yaşı $12,7 \pm 16,54$ (en küçük sığınmacı 3 günlük-en büyük ise 74 yaşındayd1) olup, ortanca değer 4 olarak bulunmuştur. Başvuranların 497'si (\%55,8)'i kadın, 655'i $(\% 67,5)$ çocuk olup, yaş gruplarına göre dağılım Tablo 1'de gösterilmiştir. Enfeksiyon, en sık başvuru nedeni olup $(519 ; \% 58,2)$ bunu gastroistestinal sistem, genitoüriner sistem ve endokrinolojik problemler $(93 ; \% 10,4)$, koruyucu hekimlik (90; \%10,1), dermatolojik problemler $(77 ; \% 8,6)$, ağrı ve ortopedik sıkıntılar $(76 ; \% 8,5)$ ve diğerleri $(36 ; \% 4,0)$ takip etmektedir. Başvuru nedenlerinin yaşa göre dağılımlarına bakıldığında, çocuklarda enfeksiyon nedeni ile başvuruların en sık olduğu gözlenmiştir (Tablo 2).
Tablo 1. Katılımcıların yaş gruplarına göre dağılımı

\begin{tabular}{|c|c|c|c|}
\hline & & $\mathrm{n}$ & $\%$ \\
\hline \multirow{6}{*}{$\begin{array}{l}\text { Çocuk } \\
\text { yaş } \\
\text { grubu }\end{array}$} & $\begin{array}{l}\text { Bebeklik } \\
(0-12 \text { Ay) }\end{array}$ & 266 & 29,9 \\
\hline & $\begin{array}{l}\text { Oyun Çocuğu } \\
\text { (13-36 Ay) }\end{array}$ & 153 & 17,2 \\
\hline & $\begin{array}{l}\text { Okul Öncesi } \\
\text { (37-60 Ay) }\end{array}$ & 82 & 9,2 \\
\hline & $\begin{array}{l}\text { Okul Çocuğu } \\
\text { (5-12 Yaş) }\end{array}$ & 89 & 10,0 \\
\hline & $\begin{array}{l}\text { Adölesan } \\
\text { (12-19 Yaş) }\end{array}$ & 65 & 7,3 \\
\hline & Toplam & 655 & 73,5 \\
\hline \multirow{5}{*}{$\begin{array}{l}\text { Erişkin } \\
\text { yaş } \\
\text { grubu }\end{array}$} & $\begin{array}{l}\text { Genç Erişkin } \\
\text { (20-24 Yaş) }\end{array}$ & 49 & 5,5 \\
\hline & $\begin{array}{l}\text { Erken Yaşlılık } \\
(25-45)\end{array}$ & 118 & 13,3 \\
\hline & $\begin{array}{l}\text { Orta Yaşlilik } \\
(46-59)\end{array}$ & 53 & 5,9 \\
\hline & $\begin{array}{l}\text { Yaşlilık } \\
(60-74)\end{array}$ & 16 & 1,8 \\
\hline & Toplam & 236 & 26,5 \\
\hline \multicolumn{2}{|l|}{ Toplam } & 891 & 100 \\
\hline
\end{tabular}

Tablo 2. Başvuru nedenlerinin erişkin ve çocukların yaş gruplarına göre dağılımı

\begin{tabular}{|l|l|l|l|l|l|l|}
\hline \multirow{2}{*}{ Yaş grupları } & \multicolumn{6}{|c|}{ Başvuru nedenleri n (\%) } \\
\cline { 2 - 7 } & AOS & ENF & KH & GGE & DERM & DİG \\
\hline Bebeklik & $11(14,5)$ & $156(30,1)$ & $34(37,8)$ & $27(29,0)$ & $31(40,3)$ & $7(19,4)$ \\
\hline Oyun çocuğu & $4(5,3)$ & $111(21,4)$ & $17(18,9)$ & $11(11,8)$ & $5(6,5)$ & $5(13,9)$ \\
\hline Okul öncesi & $9(11,8)$ & $49(9,4)$ & $6(6,7)$ & $6(6,5)$ & $9,(11,7)$ & $3(8,3)$ \\
\hline Okul çocuğu & $5(6,6)$ & $60(11,6)$ & $3(3,3)$ & $11(11,8)$ & $7(9,1)$ & $3(8,3)$ \\
\hline Adölesan & $8(10,5)$ & $36(6,9)$ & $5(5,6)$ & $5(5,4)$ & $7(9,1)$ & $4(11,1)$ \\
\hline Çocuk toplam & $37(48,7)$ & $412(79,4)$ & $65(72,2)$ & $60(64,5)$ & $59(76,6)$ & $22(61,1)$ \\
\hline 19-24 Genç erişkin & $7(9,2)$ & $24(4,6)$ & $4(4,4)$ & $6(6,5)$ & $4(5,2)$ & $4(11,1)$ \\
\hline 25-45 Erken yas & $22(28,9)$ & $53(10,2)$ & $11(12,2)$ & $17(18,3)$ & $8(10,4)$ & $7(19,4)$ \\
\hline 46-59 Orta yas & $10(13,2)$ & $21(4,0)$ & $9(10,0)$ & $6(6,5)$ & $5(6,5)$ & $2(5,6)$ \\
\hline 60-74 Yaşlıl1k & $0(0,0)$ & $9(1,7)$ & $1(1,1)$ & $4(4,3)$ & $1(1,3)$ & $1(2,8)$ \\
\hline Yetişkin toplam & $39(51,3)$ & $107(20,6)$ & $25(27,8)$ & $33(35,5)$ & $18(23,4)$ & $14(38,9)$ \\
\hline Genel toplam & $76(100,0)$ & $19(100,0)$ & $90(100,0)$ & $93(100,0)$ & $77(100,0)$ & $36(100,0)$ \\
\hline
\end{tabular}

AOS: Ağrı ve Ortopedik Sorunlar

KH: Koruyucu Hekimlik

DERM: Dermatolojik, Allerjik sorunlar

*Sütun yüzdeleri gösterilmiştir.
ENF: Enfeksiyon

GGE: Gastrointestinal, Genitoüriner ve Endokrin Sorunlar

DİG: Diğger 
Tablo 3. Katılımcıların reçete alma durumları ve yazılan ilaç dağılımları

\begin{tabular}{|l|l|l|l|}
\hline & & $\mathrm{n}$ & $\%$ \\
\hline Reçetelendirilen & Var & 502 & 56,3 \\
\cline { 2 - 4 } & Yok & 389 & 43,7 \\
\cline { 2 - 4 } & Toplam & 891 & 100 \\
\hline \multirow{4}{*}{ İaç adları } & Var & 432 & 86,1 \\
\cline { 2 - 4 } & Yok & 70 & 13,9 \\
\cline { 2 - 4 } & Toplam & 502 & 100 \\
\hline \multirow{4}{*}{ grubu } & Antibiyotik & 244 & 27.4 \\
\cline { 2 - 4 } & Analjezik & 235 & 26.4 \\
\cline { 2 - 4 } & Dermatolojik & 61 & 6,8 \\
\cline { 2 - 4 } & Diğerleri & 261 & 29,3 \\
\cline { 2 - 4 } & Toplam & 502 & 56,3 \\
\hline
\end{tabular}

Başvuranların 41 'inde $(\% 4,6)$ tetkik istenmiş olup, bu tetkikler surası ile 23'ü tam idrar analizi $(\% 53,7)$, 17'si hemogram $(\% 41,5), 15$ 'i biyokimyasal tetkik $(\% 36,6), 7$ 'si $(\% 17,1)$ gebelik testi, 1 'i parazit $(\% 2,4), 1$ 'i seroloji $(2,4)$, 1 'i tiroid fonksiyonları $(2,4)$ şeklindedir. Tetkik isteme sayısı erişkin ve çocuklarda aynı olmakla birlikte (sırası ile 21 ve 20), yüzde olarak bakıldığında, çocuklardan istenen tetkiklerin daha az olduğu ortaya çıkmaktadır (sırası ile $\% 8,9$ ve 3,1 ).

Başvuruların 502'sine $(\% 56,3)$ reçete yazılmış olup 432 $(\% 86,1)$ tane reçete kaydında verilen ilaçlar açık olarak yazılmıştır, geri kalanında sadece reçete verildiği not edilmiştir. Tablo 3'te reçete edilen ilaçlara ait sonuçlar gösterilmiştir.

\section{Hekimlerle Yapılan Görüşsmelerin Değerlendirilmesi}

Hekimlerin, Suriyeli göçmen ve mültecilere verdikleri hizmet sürecine ilişkin görüşleri; sözlü iletişim, sağllk kayıtları, hasta hekim ilişkisi ve Türkiye'deki sağlık çıktılarına etkileri başlıkları altında değerlendirilmiştir.

Doktorlar, hastalarla kendileri arasında dil farklılı̆̆ nedeniyle anlaşma konusunda problem yaşadıklarını, onların problemlerini anlayamadıkları için, tercüman kullanmak zorunda kaldıklarını; fakat tercümanın da kendilerine problemleri ne kadar doğru anlattıklarına emin olamadıklarını ve verdikleri önerilerin ya da tedavilerin ne derece anlatılabildiğinden emin olmadıklarını belirtmektedirler.

"Hayır, çünkü ne ben onu çok iyi anlayabiliyorum ne de onlar benim onlara ne dediğimi anlayabiliyorlar. İlacını yazıyorum, ama o nasil kullanıyor, eczacı bunu nasıl anlatıyor bilemiyorum."

Birçok hastanın kimlik numarası bulunmamaktadır ve ilaç alabilmek için akrabaları aracılığıyla reçeteli ilaç almaya çalışmaktadırlar. $\mathrm{Bu}$ durum, kime bakım verdiklerini bilemeyen hekimlerin ileride sorumlu tutulmaktan korkmalarına ve mülteci hastalara olan güvenlerinin sarsılması ile hasta hekim ilişkisine yansımaktadır. Hastaların, önceki sağlık bilgilerinin elde olmamas1 nedeniyle tedavi verme konusunda zorlandıklarını belirtmektedirler. Mülteciler ise, sorunlarını diledikleri gibi çözemedikleri için hekimlere öfkelenmektedir. Hekimler, mültecilerin sağlık alanındaki taleplerinin yerine getirilmesinde bu taleplerin kendilerine yararını dikkate almayan ve tüketime yönelik bir ısrar içinde olduklarını düşünmektedirler. Özellikle, üniversitesi hastaneleri gibi üçüncü basamak sağlık hizmetlerine sevk taleplerinin yerine getirilmemesi sorun oluşturmakta, bu durum hekimleri, çaresiz bırakmaktadır ve var olan mültecilerin bakımlarını üstlenmekte isteksizleşmelerine neden olmaktadir.

Hastaların tavırlarının da saldırgan olduğu ve bu durumun çalışma motivasyonlarını bozduğunu, profesyonel tercümanların çalıştığı merkezlerde sığınmacıların bakılmasının daha yararlı olacağını düşündüklerini belirtmişlerdir.

"Dil anlamıyorlar, bunun hekimin çözmesi gereken bir sorun olduğunu düşünüp kendilerine her şeyi hak görüyorlar"

"Gereksiz sevk almak istiyorlar, vermezsen olay çıkarıyorlar. Sağlık güvenceleri farklı ve bu sorun yaratıor."

Hekimler, mültecilerin yaşadıkları coğrafya, nüfus vb durumlara bağlı spesifik sağlık sorunlarına sahip olduklarını, ancak kendilerinin bu konularda eğitimleri olmadığı için hastalara bu gözle yaklaşamadıklarını düşünmektedirler. Leişmanyoz gibi, Türkiye'de artık görülmeyen bulaşıcı hastalıkların Türkiye toplumu için de yeniden sorun olabileceğini, bu nedenle mülteci sağlığının aynı zamanda yerel halk için de önemli olduğunu belirtmektedirler.

"Çok farklı kendilerine özgü hastalıkları var, bu hastalıklar konusunda çok bilgimiz yok leishmania vs gibi"

Çözüm olarak tıbbi terimler konusunda deneyimli tercümanların bulunduğu ve güvenlikli birimlerde özel eğitim almış hekimlerin görev yapması önerilmektedir.

"Onlara özel bir birim kurulmalı, onların hastalıklarına daha çok hakim olabilecek kişiler yeminli tercümanla bu işi yapmalı."

"Güvenlik sağlanmalı, hekim açısından"

\section{TARTIŞMA}


Mülteci ve sığınmacı sağlığı ile ilgili yaygın iki paradigma mevcuttur; birincisi mültecilerin politik bir topluluk olarak nesnelleştirilmesi diğeri ise mülteci sağlığının hastalık ve patolojiye indirgenmesidir. ${ }^{10,13}$ Çalışmamızda, TSM'de sunulan hizmetin ikincil türde olduğu ve başvuru üzerinden yürütüldüğü anlaşılmaktadır. Öte yandan sınırlı da olsa, verilen hizmete ait kayıtların yeterli bir şekilde tutulduğu söylenemez. Kayıtlarda çok az parametreye yer verilmekte ve bunlar gelişigüzel doldurulmaktadır. Örneğin birçok tedavi ayrıntılı olarak yazılmamıştır. Yakınma ve tanı ayrı ayrı yer almadığı gibi, bu parametreler herhangi bir kodlama sistemine uygun olarak işlenmemektedir. Kayıtlardan sevk yapılıp yapılmadığı, hastalığın gelişme durumu vb izlenememektedir. Bu nedenle gerek istatistik anlamında, gerekse sağlık hizmetinin değerlendirilmesi anlamında, uygun bir kayıt sisteminden söz edilmesi mümkün değildir. $\mathrm{Bu}$ durum, mülteciler kadar toplum sağlığı açısından da sorunlara yol açabilecektir. Halbuki ülkemizde BB da çok gelişmiş bir kayıt sistemi bulunmaktadır. Orta Doğu'da süregelen savaş durumu yıllar içerisinde mülteci ve sığınmacılara yönelik bir sağlık hizmetinin ve kayıt sisteminin geliştirilmesi için yeterli zamanı sağlamış olsa da bu alanda gelişmenin sağlanamaması üzücüdür.

Çalışmamızda, bir yıl içerisinde yapılan başvuruların her birinin farklı bireylere ait olması ve koruyucu hekimlik uygulamalarının başvuru temelinde ve oldukça az sayıda olması, kapsamlı ve sürekli bir bakımın sağlanamadığını göstermektedir. Mülteci topluluklarının sürekli ve kapsamlı bir bakım açısından, en çok ihtiyaç içerisinde olan gruplar olduklarını gözden kaçırmamak gerekir ${ }^{14}$.

Çalışmamızda, başvuruların en çok enfeksiyon nedeni ile yapıldığııı gözlemlenmiştir. Ürdün'de, Suriye'den sığınmacı olarak gelen kadın ve çocukların beslenme durumunun incelendiği araştırmada kronik malnütrisyon prevalansının, belirgin olarak yüksek olduğu, anemi tanısının ise hem çocuklarda hem de kadınlarda \%40 oranında olduğu tespit edilmiştir. ${ }^{16}$ Birçok çalışmada sığınmacı ve göçmenlerde depresyon, posttravmatik stres bozukluğu, psikosomatik şikayetler, anksiyete, uyku bozuklukları, beslenme bozuklukları, anemi, çocuklarda büyüme ve gelişme geriliklerinin yanı sıra fiziksel şiddet ve buna bağl1 yaralanmalar, cinsel istismar, HIV/AIDS dâhil cinsel yolla bulaşan enfeksiyonlar (CYBE), istenmeyen gebelikler, riskli gebelikler, düşükler ve doğum komplikasyonları ve diş sağlığı sorunları gibi hastalıklar nedeni ile başvuru bizim çalışmamızda gözlemlenmemiştir. 4,8,7,17,18,19 Ülkemizde yapılan bir çalışmada, sığınmacılar arasinda sifiliz, HIV/AIDS, hepatit B ve C prevalans1 yüksek saptanmıştır ve gerek artan sayıda göç aldığı, gerekse bir geçiş bölgesi olduğu için, sığınmacı-mülteciler için uygun sağlık yaklaşım politikaları oluşturmak zorunda olduğu belirtilmektedir. ${ }^{18}$ Bizim çalışmamızda, sadece bir tek serolojik test yapıldığı gözlenmektedir. Bu durum, birinci basamakta yapılması gereken taramaların da sı̆̆ınmacılar için yeterince yerine getirilmediğini düşündürmektedir. Yine çalışmamızda, ruhsal duruma ilişkin herhangi bir tanı bulunmamaktadır. Bunun nedenleri arasında öncelikle kayıtların yetersizliği, göçmenlere özgü bir kayıt sisteminin bulunmayışından söz edilebilir. Öte yandan çalışmamızda, tüm hastaların sadece bir kez başvurmuş olması sürekli ve kapsamlı bir bakım alamadıklarının göstergesidir. Aile hekimliğinde hasta hekim arasındaki güven ilişkisi tekrarlayan görüşmeler ile sağlanmaktadır. Özellikle cinsel istismar, CYBE, psikolojik yakınmalar için bu güven ilişkisi zorunludur. Farklı birimlerden hizmet alan hastalarla, özellikle psikolojik ve kronik durumlarla ilgili tanı koymada gerekli olan sürekli temas kurulamamıştır. Bunlar tanıların genel ve akut sorunlara yönelik olmasına neden olmuş olabilir. Yine hastaların sadece $\% 10$ başvurusunun koruyucu hekimlik ile ilgili olması, kapsamlı bir bakımın gerçekleşmediğini göstermektedir. Türk Tabipleri Birliği'nin yayınladığı olağandışı durumlar için hızlı sağlık değerlendirilmesi protokolleri kapsamında mülteci ve sığınmacıların toplu şekilde kamplarda, kamu binaları benzer yerlerde yaşamalarının bulaşıcı hastalı riskini arttırdığı bildirilmektedir. Özellikle bağışıklama programlarında ve koruyucu hizmetlerde aksama olması salgınların etkilerini arttırmaktadır. ${ }^{17}$ Türkiye'de 2012 de 349 kızamık olgusu yaşanmıştır. Kızamık tanısı açısından, Suriyeli sığınmacılar gelmeden önceki duruma göre 20 kat artış olduğu belirtilmektedir. ${ }^{20}$ Çalışmamızda, kadın ve çocuk başvurularının yüksek olması durumun önemini daha da arttırmaktadır Türkiye'de mülteciler ile ilgili olarak yapılan çalışmalarda, çalışmanın yapıldığı yere göre farklı cinsiyet ve yaşların ön plana çıkmaktadır. Kampta kalan Suriyelilere yönelik yapılmış bir çalışmada erkeklerin oranı daha fazla iken yaş grubu olarak en çok 15-35 yaş aralığı dikkati çekmektedir. ${ }^{21}$ Öte yandan Hatay ilinde 2011 ve 2013 yılları arasında beyin cerrahi servisinde tedavi edilen 186 hastanın kayıtları incelendiğinde, hem erişkin hem de çocuk hastalarda erkek oranını daha fazla olduğu görülmektedir. ${ }^{22}$

İstenen tetkiklerin en başında idrar incelemesi gelmektedir. Çok fazla tetkik istenmemiş olmasına rağmen, $\% 17$ oranında gebelik testi yaptırılmıştır. Göçmen kadınların sağlık sorunu olarak en sik jinekolojik ve psikolojik yakınmaların olduğu, \%65'i sağlık durumlarını zayıf-kötü olarak belirtilmiştir. ${ }^{5}$ Göç edilen yerlerde, olanak üst düzeyde olsa da kadınların aile planlaması başta olmak üzere üreme sağlı̆̆ı ile ciddi sıkıntılar çektiği görülmektedir. ${ }^{17,23}$

Mülteci ve sığınmacılar sağlık hizmetine, tanı-tedavi olanaklarına, ilaca ulaşım ve koruyucu hizmetler konusunda sıkıntı çekmektedirler. ${ }^{4,24}$ Dil sıkıntısı insanların kendi kendini ifade edememelerine neden olmaktadır. Gidilen bölgede irk ve dil konusunda ayrımcılık yapılması göç eden kişilerde kronik hastalıkların artışıla sonuçlanmaktadır. ${ }^{4,25}$ 
Öte yandan sığınmacılar, gerekli sağlık hizmetine etkin olarak ulaşamazken bakım veren hekimler de kendilerini yetersiz ve tehlikede hissetmektedirler.

İletişimsizlik sorununu çözmek için, birçok ülkede tercüman görevlendirilmektedir. ${ }^{26}$ Profesyonel olmayan kişilerin benzeri işlerde görev yapması da yeni sorunlara yol açabilmektedir. ${ }^{23} \mathrm{Bu}$ sıkıntıların yaşanmaması için, tercümanların gerekli bilgi ve tecrübeye sahip olup, gizlilik ve tarafsızlık ilkesine bağlı olmaları gerekmektedir. ${ }^{23}$ Günde ortalama 3,4 hasta gibi az sayıda hastanın başvurması iletişimsizliği arttıracak zaman darlığı sorununun bulunmadığını düşündürmektedir. $\mathrm{Bu}$ nedenle dil sorunu en önemli engel gibi görünmektedir.

Bu göçün, dolaylı ama ciddi bir etkisi de Kilis Devlet Hastanesi'nde görülmüştür. 2011-2014 tarihi arasındaki verilerine göre savaş yaşanan olumsuz ortam yüzünden toplam 31 hemşire, 20 sağlik memuru ve 9 ebe tayin istemek zorunda kalmıştır. ${ }^{22}$ Kilis Devlet Hastanesinde oluşan gereksinimler nedeniyle, Temmuz 2012-Aralık 2013 tarihleri arasında 353 geçici personel çalıştırılmıştır. ${ }^{22}$

Araştırmamızın tek bir merkezde yürütülmüş olması, çalışmanın sınırlılığını oluşturmakla birlikte, bölgedeki sağllk hizmetlerinin ülkenin diğer bölgeleri ile benzer olması ve mültecilerin heterojen karakteri, elde edilen sonuçların önemli bir bilgi oluşturduğunu düşündürmektedir. Öte yandan çalışmanın birinci basamakta ve karma yöntem kullanılarak yapılması ve ekonomik yöne dikkati çekmesi nedeni ile, bu alanda benzerlerinden farklı bir çalışmadır. Bu alanda, daha geniş ölçekli çalışmalara gereksinim vardır.

\section{SONUÇ}

Mülteci ve sığınmacılar, gerekli sağlık hizmetlerini dil eksikliği, iletişim yetersizliği, hastalara ait eski sağlık kayıtlarının bulunmayışı, sağlık kurumlarına başvuruların takipsiz olması gibi nedenlerle, etkin bir biçimde kullanamamaktadır. Birinci basamakta, bu kişilerin bakımını üstlenmiş olan hekimler kendilerini bu konuda yetkin görmemekte ve yararlı olduklarını düşünmemektedirler. $\mathrm{Bu}$ nedenle, dil problemini ortadan kaldıracak daha etkin hizmetler planlanmalı, öncelikle de sığınmacı sorununu ortadan kaldırmak ya da en aza indirmek için barış ortamının geliştirilmesi gerekmektedir.

\section{KAYNAKLAR}

1. Merill S, Hodge GD. The war machine and global health: A critical medical anthropological examination of the human costs of armed conflict and the international violence industry. AltaMira Press, Lanham (2010).

2. Yusuf S. Anand S. Can medicine prevent war? BMJ; 1998;317:1669-70.
3. Saçaklığlu F. Kavramlar yaşamı kavramakta mı? Olağandışı durumlarla ilgili bazı kavramlar konusunda bir tartsşma. Toplum ve Hekim. 2001;16(4):244-8.

4. Adanu RMK, Johnson TRB. Migration and women's health. International Journal of Gynecology and Obstetrics. 2009;106:179-181.

5. Topcu S, Başer A. Göç ve sağlık. C.Ü. Hemşirelik Yüksekokulu Dergisi. 2006;10 (3):37-41.

6. http://www.unhcr.org/pages/49e45c366.html. (Accessed date : 19 September 2015)

7. City limits: Urbanisation and vulnerability in Sudan Khartoum case study.HPG Commissioned Report group. Accessed at August 2015. http://www.odi.org/sites/odi.org.uk/files/odiassets/publications-opinion-files/6520.pdf

8. Karadağ Ö. Altıntaş KH. Mülteciler ve Sağlık. TAF Prev Med Bull; 2010;9:55-62.

9. http://www.data.unhcr.org/syrianrefugees /regional.php (Erişim tarihi: 16 Temmuz 2015)

10. http://www.tbmm.gov.tr/komisyon/insanhaklari/ pdf01/179-199.pdf (Erişim tarihi:10 Ağustos 2015)

11. http://eur-lex.europa.eu/legalcontent/en/TXT/?uri=CELEX:32001L0055

(Acsessed at 10 August 2015)

12. https://mirekoc.ku.edu.tr/sites/mirekoc.ku.edu.tr/file s/LT\%C4\%B0CA\%20VE\%20G\%C3\%96\%C3\%87 \%20ULUSAL\%20EYLEM\%20PLANI.pdf (Erişim tarihi 10 Ağustos 2015)

13. Yıldız Ö. Türkiye kamplarında Suriyeli sığınmacılar: Sorunlar, beklentiler, Türkiye ve gelecek algisı sosyoloji araştırmaları dergisi. Journal of Sociological Research - 2013;11:41-167.

14. Sahlool Z, Sankri-Tarbici AG, Kherallah M. Evaluation report of health care services at the Syrian refugee camps in Turkey. Avicenna J Med. 2012; 2(2): 25-28.

15. http://www.nd.edu.au/downloads/research/ihrr/using _mixed_methods_approach_to_enhance_and_valida te_your_research.pdf (accessed at 16.09.2015)

16. Ekşi N. Mülteciler, Siğınmacılar, Göçmenler. Derleyen: Özkan S. "Mülteciler, Sığınmacılar, Göçmenler Konferansı". Kocaeli Üniversitesi Hukuk Fakültesi, 18 Nisan 2007.

17. Lindstrom DP., Munoz-Franco, E. Migration And Maternal Health Services Utilization İn Rural Guatemala. Social Science \& Medicine. 2006; 63:706-721.

18. Loeber O. Sexual and reproductive health issues of Turkish immigrants in the Netherlands. Eur J Contracept Reprod Health Care. 2008;13(4): 330338.

19. Sır A, Bayram Y, Özkan M. Zoraki iç göçün ruh sağlığına etkileri üzerine bir ön çalışma. Klinik Psikiyatri Dergisi. 1998;1(2): 83-88.

20. Kartarı A. Farklılıklarla yaşamak. Kültürlerarası iletişim 2.Baskı: ürün yayınları; 2006.p.35,48 
21. Aras M, Altas M, Yilmaz A, Serarslana Y, Yilmaz $\mathrm{N}$, Yengil E, et al. Being a neighbor to Syria: A retrospective analysis of patients brought to our clinic for cranial gunshot wounds in the Syrian civil war. Clinical Neurology and Neurosurgery. 2014;215:222-228.

22. Korkmaz A. Sığınmacıların Sağlık ve Hemşirelik Hizmetlerine Yarattığ 1 Sorunlar www.journalagent.com/shyd April 2014 DOI: 10.5222/SHYD.2014.037

23. Arslan MM, Zeren Z, Çelikel A, Ortanca İ, Demirkiran S. Increased drug seizures in Hatay, Turkey related to civil war in Syria. International Journal of Drug Policy. 2015;26:116-118.

24. http://www.unhcr.org/syriarrp6 (accessed date 27 June 2015).

25. Yılmaz TT. Göçün Kadın Yaşamı Üzerindeki Etkileri. T.C. Yüzüncü Yıl Üniversitesi Sosyal Bilimler Enstitüsü Sosyoloji Ana Bilim Dalı Yüksek Lisans Tezi, (Danışman; Köse, M.R.), Van. 2005

26. Kale E, Syed HR. Language Barriers and the Use of Interpreters in The Public Health Services. A Questionnaire-Based Survey. Patient Education and Counseling 2010;81:187-19. 